Pamiętnik Literacki 2016, 2, s. 235-240

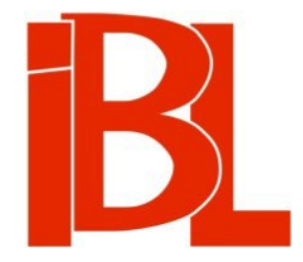

\title{
Pionierska monografia
}

Sławomir Buryła

Rec. : Tomasz Tomasik, Wojna-męskość literatura. Słupsk 2013 


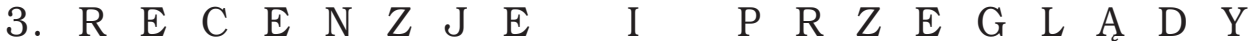

Pamiętnik Literacki CVII, 2016, z. 2, PL ISSN 0031-0514

SŁAWOMIR BURYŁA Uniwersytet Warmińsko-Mazurski, Olsztyn

PIONIERSKA MONOGRAFIA

Tomas z Tomasik, WOJNA - MESKKOŚĆ - LITERATURA. (Recenzenci: Marcin Wołk, Maciej Michalski). Słupsk 2013. Wydawnictwo Naukowe Akademii Pomorskiej w Słupsku, ss. 360.

Książka Tomasza Tomasika to przykład ciekawego, oryginalnego powrotu do tematyki drugiej wojny światowej. Najnowsze badania nad literatura powstała w okresie wojny i okupacji, jak i nad tą dotyczącą problematyki wojny i okupacji, zdominowała niezwykle prężnie rozwijająca się refleksja nad prozą i poezją Holocaustu. Artykuły i monografie o Zagładzie czy rozprawy doktorskie przyrastają w imponującym tempie. Mówię to jako ktoś, kto sam ma swój udział w tym procesie, a jednocześnie ktoś, kogo nie opuszcza świadomość, że również utwory ukazujące inne obszary drugiej wojny światowej domagają się nowego spojrzenia. Chciałoby się powtórzyć po kilkudziesięciu latach tezę Janusza Sławińskiego: „Wojna wstrząsnęła całym systemem naszej literatury; była przełomem, który poprzez swoje wielorakie skutki dzieje się jakby nadal w świadomości literackiej” . „Czasy pogardy” jednak nie tylko towarzyszą artystom i luminarzom słowa, ale też wpływają na autoidentyfikacje narodowe, wyobrażenia o nas samych. Są to bowiem problemy i teksty wciąż żywe, z kręgu tych, które budzą spore emocje, czego dowodem choćby dyskusja wokół Festung Warschau Elżbiety Janickiej (ściślej mówiąc: wokół fragmentu traktującego o młodzieży akowskiej)2 Wydatnie wzbogacona w ostatnich latach bibliografia przedmiotowa dotyczaca pokolenia Kolumbów odsyła do takich autorów, jak Tadeusz Drewnowski, Jerzy Święch, Andrzej Gronczewski, Andrzej Mencwel, Stanisław Bereś, Zbigniew Majchrowski, Stanisław Stabro, Bronisław Maj, a z młodszych - Paweł Rodak i Elżbieta Janicka. W roku 2012 ukazał się tom Pokolenie 1920, plon konferencji naukowej zorganizowanej przez Uniwersytet Humanistyczno-Przyrodniczy im. Jana Kochanowskiego w Kielcach, a rok wcześniej Biedny język Piotra Mitznera ${ }^{3}$.

Wojna - męskość - literatura składa się z dwóch części. Pierwsza jest teoretyczna (Mity i ideologie), druga - analityczna (Konfrontacje). W części I w rozdziale I, Wojna a męskość, Tomasik śledzi „przygodę” męskości w kulturze XIX i XX wieku. Jako egzemplifikacje literackie wybiera teksty ze środowiska „Sztuki i Narodu”. Nie pisze więc o całym pokoleniu, lecz jedynie o jego najbardziej reprezentatywnych przedstawicielach. To decyzja trafna. Mamy

J. Sła wiński, Zaproszenie do tematu. W zb.: Literatura wobec wojny i okupacji. Studia. Red. M. Głowiński, J. Sławiński. Wrocław 1976, s. 15.

2 E. J a nicka, Festung Warschau. Warszawa 2011. Z licznej grupy tekstów, a jeszcze liczniejszego zespołu krótkich i dłuższych wypowiedzi, głosów w dyskusji chciałbym wyróżnić recenzję J. G rab o w s k i e g o Na marginesie „Festung Warschau” („Zagłada Żydów” nr $8\langle 2012\rangle$ ).

3 Pokolenie 1920. Szkice do portretu zbiorowego. Red. M. Bolińska, J. Detka, M. Wójcik. Kielce 2012. - P. Mitzn er, Biedny język. Szkice o kryzysie słowa i literaturze wojennej. Warszawa 2011 . 
wszak do czynienia z grupą spójną ideowo. Dzięki takiemu wyborowi Tomasik uniknął sprowadzania całej generacji wojennej do wspólnego mianownika, co byłoby sporym uproszczeniem. Nie da się bowiem - bez świadomości zasadniczych różnic - w jednym szeregu ustawić Tadeusza Borowskiego, Andrzeja Trzebińskiego, Stanisława Lema, Kazimierza Kąkola czy Karola Wojtyły.

W kontekście młodzieży akowskiej i pojęcia męskości chciałoby się zapytać o „żydowskich Kolumbów". To oczywiście temat na inną publikację, choć nie sposób nie odnotować podobieństwa wojennych życiorysów, jak też analogii na innej płaszczyźnie - symbolicznej. Nie bez powodu „żydowscy Kolumbowie” odwoływali się do dni militarnej chwały narodu wybranego, a powstanie w getcie traktowali bardziej w kategoriach sprawdzianu męskości i przełamania stereotypów o wrodzonym tchórzostwie niż wiary w sukces militarny.

Śledząc związki wojny i płci Tomasik odnotowuje rozłączenie, a także pogłębienie społecznych oraz kulturowych ról mężczyzn i kobiet. Każda z płci ma w czasie wojny ściśle określone zadania do wypełnienia. Dla młodego chłopaka wojna jest o b i e t n i c ą m ę s k oś c i, to nadzieja na stanie się mężczyzną, w polskiej tradycji dodatkowo zespolona $z$ realizacją wzniosłego, wyzwoleńczego czynu na rzecz ojczyzny. Męskość (sfera indywidualna) spotyka się tu z żołnierskością (sfera obywatelska). Nie tylko w romantyzmie są one trudne do rozdzielenia. Współistnieją bowiem na zasadzie idealnej osmozy, wzajemnie siebie warunkując. To, co związane $z$ ojczyzną, uruchamia odniesienia metafizyczne i mistyczne; zarazem przeraża i fascynuje, stanowi przedmiot sakralizacji, deifikacji wręcz. Udział w tej świętości mogą mieć tylko mężczyźni. Dla nich bowiem kulturowo zarezerwowany jest czas trwogi i chwały; dla nich „ofiara krwi”, śmierć bohaterska, bo w obronie wartości najwyższej - wolności. „Danina krwi” - jak słusznie przypomina Tomasik - stała się w polskiej mentalności, w polskiej myśli historiozoficznej XIX wieku warunkiem koniecznym odzyskania niepodległości. Następowało mistyczne zjednoczenie krwi z ziemią. Wojna równocześnie jawiła się jako piękna przygoda (czemu daje wyraz liryka i piosenka żołnierska). Oznacza to skrywanie wątpliwych społecznie, psychicznie i moralnie aspektów wojny (co $z$ całą mocą ujawniło się w europejskiej powieści pacyfistycznej po pierwszej wojnie światowej).

Rozdział II nosi tytuł Ideologiczna triada: wojna - męskość - bohaterstwo. Badacz dowodzi w nim kulturowej trwałości i płodności połączenia wojny, bohaterstwa i męskości. Wskazuje na rejony, w których w drugiej połowie XX wieku spotkanie tych trzech kategorii powraca (np. kino hollywoodzkie). W rozdziale tym omówiono zachodni kanon bohaterstwa i męskości, wychodząc od epoki starożytnej: homeryckiego ideału wojownika, przez dziedziczące reguły antycznego kodeksu średniowiecze, krytyczne przewartościowanie rycerskości w wielkiej powieści Cervantesa, sarmacki i szlachecki wzorzec obrońcy granic oraz wiary, romantyczny „terror bohaterstwa”, po kolejne przewartościowanie, jakie przyniosła konfrontacja sarmackich, a także romantycznych koncepcji z nowoczesną wojną - jej okrutną, techniczną stroną, skutkującą rzeziami na skalę dawniej nie spotykaną.

Romantyzm inkorporował - jak pokazuje Tomasik - i heroiczny mit homerycki, i rycerski wieków średnich oraz sarmacki prototyp strażnika chrześcijaństwa i polskości. Podobnie jak w średniowieczu, również w baroku rzeczywistość często odbiegała od obowiązujących wzorów kulturowych, co nie podważa zasadności istnienia samych wzorów. Zbigniew Kuchowicz w fascynującej pracy Człowiek polskiego baroku, wyliczając liczne lęki trapiące ówczesnych ludzi, wymienia obawę przed żołnierzami: „Chłopów i mieszczan przerażały [...] oddziały pospolitego ruszenia, zachowujące się czasem niby w podbitym kraju”" ${ }^{4}$ Przypomina dni chwały oręża polskiego, bitność szlachty i zarazem odnotowuje (mniej chętnie przytaczane) świadectwa strachu, paniki i dezercji z pola walki (Cecora, Piławce, Batoh, pierwszy dzień bitwy pod Parkanami). Niezłomny rycerz, gotowy umrzeć męczeńską śmiercią za 
wiarę i ojczyznę, bywał nierzadko bestialski. Trzeba wszakże pamiętać, że w wieku XVII rozmaite przejawy okrucieństwa wobec wrogów stanowiły zjawisko raczej częste niż wyjątkowe, a polska szlachta nie wyróżniała się pod tym względem na tle innych wojsk. Jeszcze silniejszy od oddziaływania sarmackości wpływ na naszą świadomość (jak też na świadomość generacji wojennej) miały koncepcje polskiego romantyzmu (i Tomasik słusznie poświęca tej epoce najwięcej uwagi). $\mathrm{Nb}$. XVII-wieczne rozumienie męskości jest wciąż do opisania (co zostało w książce zasygnalizowane).

Część II, Konfrontacje, otwiera rozdział Pokolenie wojenne, podejmujący próbę sformułowania - raz jeszcze - kategorii wielokrotnie już wcześniej definiowanej (choćby przez Kazimierza Wykę, Lidię Burską czy Pawła Rodaka). Tomasik za centralny wyznacznik spajający generację akowską uznaje szczególną rangę czynu zbrojnego - odwagi, męstwa, włącznie z poświęceniem życia. Wojna i będąca jej konsekwencją sytuacja egzystencjalna w sposób podstawowy określają sens kategorii pokolenia wojennego. Nie bez słuszności też badacz akcentuje wyjątkową rolę systemu wychowawczego skupionego na kultywowaniu służby ojczyźnie jako wartości największej i najbardziej nobliwej. „W formułowanych w latach 30. programach wychowawczych - tych zalecanych do szkół, jak i tych wywodzonych $z$ literackich tradycji - bardzo wyraźnie ujawniała się tendencja militarystyczna. Wartościowe wychowawczo okazywało się przede wszystkim to, co wyrastało z żołnierskiego dziedzictwa. Militaryzacja kultury oznaczała także jej maskulinizację. Żołnierz, sukcesor dawnego rycerza, sarmackiego wojownika, napoleońskiego i legionowego ułana, awansował w kulturze polskiej lat 30. do rangi najważniejszej, propagandowo eksponowanej, figury męskiej identyfikacji tożsamościowej" (s. 165-166). Sądom takim wtórował w początkach lat dziewięćdziesiątych XX wieku Tadeusz Konwicki w krótkiej wypowiedzi na temat rocznicy pracy artystycznej swojego przyjaciela Gustawa Holoubka: „Należymy do pewnego pokolenia. To pokolenie było w jakiś specjalny sposób wychowywane, może dlatego że społeczeństwo przeczuwało, iż będzie wojna i trzeba młodzież do niej przygotować?"5

Rozdział II w Konfrontacjach przynosi szkic o Wacławie Bojarskim. Trubadur na wojnie, czyli sen o żołnierskim czynie (Bojarski) to nader interesujące przypomnienie biografii i dzieła autora pomijanego w refleksji nad środowiskiem „Sztuki i Narodu” (wszak swojego opracowania doczekał się nawet Zdzisław Stroiński - Ananke i Polska Mariana Kisiela6). Tomasik wybiera centralną dla Bojarskiego ideę, rodzaj obsesji, jak zdawał się to widzieć Borowski w słynnej Fraszce imperialnej. Nurtująca i nęcąca nie tylko Bojarskiego myśl o imperium, wielkim czynie i sile to - dowodzi badacz - reakcja na klęskę wrześniową. Pozostawiła ona głębokie ślady w psychice młodych ludzi, kształtowanych w szkole średniej przez mit państwa dysponującego niezawodną armią, „zwartego i gotowego”. Raz jeszcze zacytujmy Konwickiego, który w latach siedemdziesiątych tak o tym mówił: „Wojna przyniosła zupełne przewartościowanie. Zobaczyliśmy, że świat, w którym żyjemy, świat jakiegoś porządku, ładu nic nie znaczył. Wszystko się w naszych oczach skompromitowało, rozpadło, zobaczyliśmy na przykład, że ludzie, których uważaliśmy bez mała za świętych, to tchórze. I odwrotnie, ludzie przeciętni, "szarzy", wyrastali na bohaterów"7. Klęska wrześniowa - będąca wyzwaniem intelektualnym dla wszystkich, którzy jej doświadczyli - wedle Bojarskiego stanowiła efekt braku wielkiej idei. Ów niedostatek skutkował osłabionym morale żołnierzy. Dotkliwy bowiem był nie tyle militarny wymiar katastrofy, co jej mentalny wydźwięk oraz szybkość, $z$ jaką się

$5 \quad$ Nasze histerie, nasze nadzieje. Spotkania z Tadeuszem Konwickim. Wybór, układ P. Ka n i e c ki. Warszawa 2013, s. 270.

$6 \quad$ M. Ki i i e l, Ananke i Polska. O liryce Zdzisława Stroińskiego. Katowice 2010. Zob. też A. N ę c k a, „Poszarpany krzyk na gruzach młodości”. O poezji Zdzisława Stroińskiego. W zb.: Liryka żołnierska. Estetyka i wartości. Red. A. Paliw o d a, J. Wols ki. Rzeszów 2011.

$7 \quad$ Nasze histerie, nasze nadzieje, s. 299-300. 
ona dokonała. W pisanych przez Bojarskiego piosenkach dla żołnierzy pobrzmiewa niezłomna wiara w zwycięstwo, której zabrakło w kampanii wrześniowej. Tak to widział słabowity, walczący z gruźlicą redaktor „Sztuki i Narodu”.

Najobszerniejszy w Konfrontacjach jest fragment dotyczacy poezji Krzysztofa Kamila Baczyńskiego. Rozdział IV, Anioł na wojnie, czyli męski kompleks słabości (Baczyński), raz jeszcze omawia (inspirująco, nie odtwórczo) kwestię już po wielekroć roztrząsaną - duchową walkę artysty i żołnierza. „Wnikliwsza analiza poezji Baczyńskiego ujawnia wewnętrzny konflikt wrażliwego moralnie artysty, dramat męskości zranionej przez wojnę i przez konsekwencje poddania się presji etosu żołnierskiego" (s. 245). Tomasik ukazuje istotę dylematów Baczyńskiego jako rozdarcie między światem ojca (żołnierskości, obowiązku, odwagi) a światem matki (poezji, wrażliwości, moralnego dyskomfortu i trudności w podejmowaniu decyzji). Tak jak w prozie Gajcego, tak też w wierszach Baczyńskiego wojna przedstawia się jako moment nierozwiązywalnych sprzeczności.

Rozdział V nosi tytuł Homer na wojnie, czyli od psychologii męskości do etyki męskości (Gajcy) i podejmuje szczególnie mocno zarysowany u autora Misterium niedzielnego problem zdrady. Tomasik koncentruje się na analizie prozy Gajcego. W niej najpełniej dochodzą do głosu aporie wojennego czasu. W Pawle i Twarza w noc Gajcy upomina się o męskie prawo do strachu oraz do lęku przed tchórzostwem. Obnaża „antyhumanitarny rys ideologi i żołnierskiej” (s. 295), ujawnia tragizm, „polegający na ocaleniu męskiego honoru kosztem życia - własnego i cudzego" (s. 294). Rekonstruując jaśniejszą stronę dzieł Gajcego wydobywa Tomasik w Cenie fantazmat ocalającej kobiecości, dobrze znany z epoki romantycznej. „Metafizy ka kobi ec ości o calają c ej skażonego moralnie mężczyznę [...] to jeszcze jeden ze sposobów wyzwolenia się Gajcego spod deprawującego psychicznie i moralnie działania ideologii męskości żołnierskiej” (s. 303).

Jedynym szkicem w Konfrontacjach, który nie dotyczy środowiska „Sztuki i Narodu”, jest Mitologia męskości $w$ „Kamieniach na szaniec” Aleksandra Kamińskiego (rozdział III). Wciąż wszakże mamy do czynienia z tą samą generacją, uformowaną przez identyczny zespół pojęć i autorytetów. To jeden $z$ najciekawszych fragmentów w całej monografii, również za sprawą ostatnio wydanej książki Festung Warschau Janickiej. Tomasik buduje wywód polemiczny wobec interpretacji Janickiej. Nade wszystko mocno akcentuje zideologizowany charakter opowieści Kamińskiego; przywołuje też inną powstałą podczas okupacji książkę tego autora, Wielka grę, słusznie przypominając, że „Miała ona pełnić funkcję podręcznika młodego konspiratora i dywersanta, a po podziale Szarych Szeregów w listopadzie 1942 roku uznano ją za lekturę stosowna dla Bojowych Szkól, czyli harcerzy w wieku 15-17 lat zaangażowanych w mały sabotaż" (s. 214). Zarówno więc Wielka gra, jak i Kamienie na szaniec zostały pomyślane jako publikacje mające określone cele propagandowe do spełnienia, jako jeden z elementów wojennego wychowania młodzieży. Niekiedy zapominamy, że okupacja to czas rozluźnienia norm moralnych, upadku obyczajów (na co niejednokrotnie narzekano w prasie podziemnej). Kamienie na szaniec konstruują model zachowań i postaw, a nie starają się ukazać złożoną prawdę o rzeczywistości okupacyjnej. Podnoszone przez Janicką milczenie o losie Żydów i żydowskiej młodzieży da się tłumaczyć właśnie propagandowym aspektem tego utworu, który nie aspirował do panoramy - choćby skrótowo i pobieżnie zarysowanej - okupacyjnej codzienności.

Przynajmniej na dwa sposoby można dziś wracać do problematyki wojny i okupacji. Wolno - drogą żmudnej kwerendy - przyswajać teksty mniej znane, podejmować tematy jeszcze nie opisane, wykorzystując do tego nowe metodologie. Ale można również sięgnąc po sławnych autorów oraz po słynne dzieła, niemal emblematyczne, i posiłkując się owymi metodologiami wydobywać $z$ nich kwestie do tej pory nie poruszane. Nowe metodologie to nowe spojrzenie na utwory niekiedy zasklepione interpretacyjnie. Tomasik proponuje to drugie podejście. Zarówno użyta metodologia, jak pojęcie męskości idealnie korespondują z generacją „Sztuki i Narodu”. Wprawdzie zagadnienie męskości oraz interesujące badacza 
stereotypy dotyczące wojny, żołnierskości, bohaterstwa stanowiły przedmiot wcześniejszych szkiców (choćby studium Wojna i forma Marii Janion), ale nikt przed autorem omawianej monografii nie dokonał ich całościowej prezentacji.

Pośród innych zalet pracy Tomasika chciałbym wskazać na dwie - wcale nie takie częste obecnie w literaturoznawstwie. Wojna - męskość - literatura napisana jest językiem komunikatywnym, jasnym. Badacz nigdy nie traci z oczu czytelnika, z którym stara się przez cały czas utrzymywać kontakt intelektualny. Odwołując się do nowych metodologii - co u Tomasika oznacza zwykle wykorzystanie narzędzi krytyki genderowej - nie nasyca swego wywodu nadmierną ilością fachowego słownictwa, zbytecznym żargonem naukowym, który często bardziej utrudnia lekturę, niż dowodzi erudycji autora. Tomasik ma przy tym świadomość innego faktu - ostrożności, z jaką należy podchodzić do tekstu, gdy sięga się po ustalenia $z$ obszaru współczesnej humanistyki. Pozwala zatem najpierw przemówić dziełu, przeprowadzając skrupulatną analizę filologiczną. To właśnie umiejętności interpretacyjne Tomasika i samoświadomość metodologiczna stanowią o największej wartości recenzowanej rozprawy.

W rozbudowanej bibliografii - erudycyjnej i komplementarnej - zabrakło kilku opracowań, które mogłyby wzbogacić przemyślenia Tomasika. Kiedy omawia on w części teoretycznej kluczowe połączenie wojny i męskości w okresie międzywojennym, wypadałoby krótko wspomnieć tom $W$ stronę faszyzmu Ferdynanda Goetla - przez lata niesłusznie odczytywany jako prosta apologia niemieckiego faszyzmu. A przecież Goetel to jeden z kodyfikatorów przedwojennego „wychowania do męskości”. Należałoby też przywołać jego wspomnienia zebrane w Czasie wojny. Przynoszą one ciekawe przewartościowanie kwestii bohaterstwa i rozumienia polskości (m.in. pod wpływem tragedii powstania warszawskiego).

W recenzowanej monografii nie znajdziemy także wzmianki o innej ważnej książce o przenikliwych reportażach Antoniego Sobańskiego Cywil $w$ Berlinie, wydanych przed kilku laty przez Tomasza Szarotę. Sobański dostarcza wielu ciekawych spostrzeżeń na tematy zajmujące Tomasika. Chodzi m.in. o analizowana przez Sobańskiego rolę munduru w społeczeństwie niemieckim w połowie lat trzydziestych (Naród $w$ mundurze), pilnowanie w Trzeciej Rzeszy wyraźnych granic między sferą kobiecości a sferą męskości (Cywile, Reichstag i ksiażkil).

Skrupulatnie prezentując wzorce męskości, autor monografii pominął w wykazie bibliograficznym klasyczną pracę Marii Ossowskiej Ethos rycerski i jego odmiany. Być może dlatego, że uznał to za nazbyt oczywiste odniesienie. Wyraźnie brakuje natomiast w intrygujących refleksjach Tomasika odwołań do esejów Gottfrieda Benna ze zbioru Po nihilizmie (zwłaszcza tam, gdzie Tomasik mówi o epoce antycznej, i tam, gdzie przywołuje dzieje Trzeciej Rzeszy). Domagałyby się skomentowania (rozwinięcia) w monografii Wojna-męskość - literatura takie oto sądy: „Dorycki jest wszelkiego rodzaju antyfeminizm. Dorycki jest mężczyzna zamykający domowe zapasy i zabraniający kobietom przyglądać się igrzyskom; tę, która przekroczy Alfejos, strąca się ze skały. Dorycka jest miłość do chłopców, aby bohaterstwo zostało przy mężczyźnie, miłość do wojennych wypraw; takie pary stały obok siebie jak mur i ginęły razem. Była to erotyczna mistyka: wojownik obejmował chłopca ramieniem, jak mąż żonę, i przenosił nań swą arete, łączył go ze swoimi cnotami”"

Tomasik pomija ważną dla rozumienia męskości w literaturze lat 1918-1939 powieść Adolfa Rudnickiego Żołnierze. Jestem świadomy, iż dokonana przez badacza prezentacja nie ma charakteru skrupulatnego wyliczenia czy przybliżenia wszystkich tekstów dotyczących wojny i męskości - nie miałoby to zresztą większego sensu. Chodzi o przedstawienie tych

8 A. Sobańs ki, Cywil w Berlinie. Oprac. T. Szar ot a. Warszawa 2006.

9 G. Ben n, Świat dorycki. O zwiazkach sztuki władzy. W: Po nihilizmie. Eseje, szkice, fragmenty. Wybór, oprac. H. Orłows ki. Poznań 1998, s. 98-99 (przeł. R. Turczyn). 
najbardziej znaczących. Żotnierze jednak należą do dzieł kluczowych i trudnych do pominięcia $\mathrm{z}$ punktu widzenia kategorii męstwa, wojny, bohaterstwa. Józef Wróbel w Mierze cierpienia tak pisze o wymowie utworu Rudnickiego: „Wojna ma być sprawdzianem i żołnierzy, i społeczeństwa, które pielęgnuje małe, niegroźne dla nikogo prócz jego samego mity, które nieświadomie gloryfikuje własną słabość, które fascynuje się tym, co pozorne - takie wnioski mógł wyciągnąc uważny i nieuprzedzony czytelnik. Trzeba będzie zapłacić za anachroniczne marzenia, za opóźnienia cywilizacyjne, za brak spójnej wizji narodu jako całości i za brak programu nowoczesnego wychowania jednostek i zbiorowości" ${ }^{10}$.

Wielokrotnie akcentowany w pierwszej części rozprawy namysł nad kobiecością i męskością w perspektywie wzajemnie wykluczających się atrybutów przydawanych każdej płci należałoby - choćby krótko - uzupełnić spostrzeżeniami Kathrin Kompisch. W Sprawczyniach (w 2012 roku opublikowanych w języku polskim) niemiecka autorka opatruje znakami zapytania powszechne i bezkrytycznie przyjmowane przekonanie o „miękkiej”, „biernej” i łagodnej naturze kobiet. Jak dowodzi, w państwie Hitlera kobiety - zatrudniane jako służba pomocnicza w jednostkach SS czy Gestapo - wykazywały się niejednokrotnie okrucieństwem dorównującym okrucieństwu mężczyzn ${ }^{11}$. $Z$ historii obozów koncentracyjnych znamy przecież takie nazwiska, jak Elsa Koch czy Irma Grese.

Po lekturze książki Tomasika trudno pozbyć się myśli o monografii, która stanowiłaby kontynuację podjętych przez niego rozważan, a która uwzględniłaby prozę i poezję polską między rokiem 1945 a 1989. Materiałów do inspirującej refleksji nad pojęciami męskości i wojny nie brakuje. Dość przywołać opowiadanie Moja SS Rottenführer Johanna oraz powieść Rudolf Mariana Pankowskiego. Nie mniej interesująca mogłaby się okazać inna synteza, wychodząca poza kontekst wojny i obejmująca (zaświadczone w rodzimej literaturze) przemiany rozumienia męskości w kulturze drugiej połowy XX wieku.

\section{Abstract \\ SŁAWOMIR BURYŁA University of Varmia and Masuria, Olsztyn \\ PIONEERING MONOGRAPH}

The review discusses Tomasz Tomasik's book Wojna - męskość - literatura (War-Masculinity - Literature) which is a pioneering presentation of the subject of masculinity in the context of Polish prose of the time of occupation.

J. W ró b e 1, Miara cierpienia. O pisarstwie Adolfa Rudnickiego. Kraków 2004, s. 226.

K. Kompis ch, Sprawczynie. Przeł. S. Kupisz, N. Badiyan-Siekierzycka. Warszawa 2012. 